This is the author's manuscript for publication. The publisher-formatted version may be available through the publisher's web site or your institution's library.

\title{
Consumer palatability scores and volatile beef flavor compounds of five USDA quality grades and four muscles
}

J. F. Legako, J. C. Brooks, T. G. O'Quinn, T. D. J. Hagan, R. Polkinghorne, L. J. Farmer, M. F. Miller

How to cite this manuscript

If you make reference to this version of the manuscript, use the following information:

Legako, J. F., Brooks, J. C., O'Quinn, T. G., Hagan, T. D. J., Polkinghorne, R., Farmer, L. J., \& Miller, M. F. (2015). Consumer palatability scores and volatile beef flavor compounds of five USDA quality grades and four muscles. Retrieved from http://krex.ksu.edu

\section{Published Version Information}

Citation: Legako, J. F., Brooks, J. C., O'Quinn, T. G., Hagan, T. D. J., Polkinghorne, R., Farmer, L. J., \& Miller, M. F. (2015). Consumer palatability scores and volatile beef flavor compounds of five USDA quality grades and four muscles. Meat Science, 100, 291-300.

Copyright: (c) 2014 Elsevier Ltd.

Digital Object Identifier (DOI): doi:10.1016/j.meatsci.2014.10.026

Publisher's Link: http://www.sciencedirect.com/science/article/pii/S0309174014004744

This item was retrieved from the K-State Research Exchange (K-REx), the institutional repository of Kansas State University. K-REx is available at http://krex.ksu.edu 
$21 \quad{ }^{a}$ Corresponding Author, Tel.: (435) 797-2114, Fax: (435) 797-2379,

22 E-mail address: jerrad.legako@usu.edu

23 Postal address: 8700 Old Main Hill; Utah State University; Logan, UT 84322-8700
J. F. Legako ${ }^{\text {a }, ~ J . ~ C . ~ B r o o k s ~}{ }^{\text {b }, ~ T . ~ G . ~ O ' Q u i n n ~}{ }^{\mathrm{c}}$, T. D. J. Hagan ${ }^{\mathrm{d}}$, R. Polkinghorne ${ }^{\mathrm{e}}$, L. J. Farmer ${ }^{\mathrm{d}}$, M. F. Miller ${ }^{\mathrm{b}}$

${ }^{\text {a }}$ Department of Nutrition, Dietetics \& Food Sciences, Utah State University, Logan, UT 84322 USA

${ }^{\mathrm{b}}$ Department of Animal \& Food Sciences, Texas Tech University, Lubbock, TX 79409 USA

${ }^{c}$ Department of Animal Sciences and Industry, Kansas State University, Manhattan, KS 66506 USA

${ }^{\mathrm{d}}$ Agri-Food \& Biosciences Institute, Newforge Lane Belfast, Northern Ireland BT9 5PX

${ }^{\text {e }}$ Polkinghornes Pty Ltd, 461 Timor Rd, Murrurundi, NSW 2338, Australia COMPOUNDS OF FIVE USDA QUALITY GRADES AND FOUR MUSCLES

\section{CONSUMER PALATABILITY SCORES AND VOLATILE BEEF FLAVOR}


Abstract

25 Proximate data, consumer palatability scores and volatile compounds were investigated for four

26 beef muscles (Longissimus lumborum, Psoas major, Semimembranosus and Gluteus medius) and

27 five USDA quality grades (Prime, Upper 2/3 Choice, Low Choice, Select, and Standard). Quality

28 grade did not directly affect consumer scores or volatiles but interactions $(P<0.05)$ between

29 muscle and grade were determined. Consumer scores and volatiles differed $(P<0.05)$ between muscles. Consumers scored Psoas major highest for tenderness, juiciness, flavor liking and overall liking, followed by Longissimus lumborum, Gluteus medius, and Semimembranosus ( $P<$

32 0.05). Principal component analysis revealed clustering of compound classes, formed by related mechanisms. Volatile $n$-aldehydes were inversely related to percent fat. Increases in lipid

34 oxidation compounds was associated with Gluteus medius and Semimembranosus, while greater quantities of sulfur-containing compounds was associated with Psoas major. Relationships between palatability scores and volatile compound classes suggests that differences in the pattern

37 of volatile compounds may play a valuable role in explaining consumer liking.

Keywords: beef; flavor; GC-MS; HS-SPME; Muscle; USDA Quality Grade

\section{Introduction}

Beef palatability is often believed to be most dependent on tenderness (Miller, Carr, Ramsey,

42 Crockett, \& Hoover, 2001; Miller, et al., 1995; Savell, et al., 1987). However, flavor is also

43 considered a primary palatability factor and is shown to be of great importance when tenderness

44 is acceptable (Behrends, et al., 2005a, 2005b; Goodson, et al., 2002; Killinger, Calkins,

45 Umberger, Feuz, \& Eskridge, 2004). Flavor has been identified as the single most important

46 factor in determining consumer acceptability when meat was prepared at home (Huffman, Miller, 
47 Hoover, Wu, Brittin, \& Ramsey, 1996). Beef flavor is a combination of taste and odor. While

48 taste is generally detected on the tongue as sweet, sour, salty, bitter or other taste sensations such

49 as "umami", odor or aroma is detected in the nose and plays a large role in flavor perception.

50 Numerous volatile compounds have been identified from beef, including: sulfur-containing

51 compounds, furanthiols, disulfides, aldehydes, ketones and other heterocyclic compounds (Cerny

52 \& Grosch, 1992; Farmer \& Patterson, 1991; Gasser \& Grosch, 1988; Mottram, 1991).

53 Consumers have associated increased flavor desirability with increased intramuscular fat

54 (O’Quinn et al., 2012; Smith, Savell, Cross, \& Carpenter, 1983). However, laboratory studies

55 have repeatedly found that increased intramuscular fat rarely produces increases in volatile flavor

56 compounds (Cross, Berry, \& Wells, 1980; Mottram \& Edwards, 1983; Mottram, Edwards, \&

57 MacFie, 1982). Evidence from studies on meat products suggests that fat acts as a solvent for

58 volatile compounds, thus delaying flavor release (Chevance, Farmer, Desmond, Novelli, Troy, \&

59 Chizzolini, 2000). Documentation of the effect of USDA quality grade among multiple beef

60 muscles upon volatile flavor compounds was not found in the literature.

61 Research regarding differences in flavor among muscles has focused on flavor intensity and

62 the presence of off-flavors. Calkins and Hodgen (2007) have summarized muscle rankings based

63 on flavor intensity and off-flavors. In most cases flavor intensity and off-flavors were correlated

64 with each other. Volatile compounds associated with lipid oxidation have been reported to vary

65 between muscles of the chuck and round influencing perceived flavor (Hodgen, Cuppett, \&

66 Calkins, 2006). Recently a beef flavor lexicon of beef attributes was used to determine

67 differences between top loin, top sirloin, tenderloin, and inside round steaks (Adhikari \&

68 Chambers, 2010; Miller, 2010). 
To date, no studies have assessed the palatability and volatile profile of multiple beef muscles

70 in various quality grades. The objective of this study was to determine the effects of USDA

71 quality grade and muscle on consumer palatability perception and volatile beef flavor

72 compounds.

\section{2. Materials and Methods}

74

75

76

77

78

79

80

81

82

83

84

85

86

87

88

89

90

91

\subsection{Product procurement and preparation}

Boneless striploins [Institutional Meat Purchase Specifications (IMPS) 180, North American Meat Processers Association (NAMP)], tenderloins (IMPS 189, NAMP), inside rounds (IMPS 169, NAMP), and top sirloins (IMPS 184, NAMP) were collected from three 'A' maturity (9 to 30 month animals at harvest) carcasses representing each of five USDA quality grades (Prime, Upper 2/3 Choice, Low Choice, Select, and Standard) at a commercial beef processing facility in the Midwest region of the United States. Carcasses were selected by trained individuals who assessed the amount of visual intramuscular fat of the ribeye face at the $12^{\text {th }}$ and $13^{\text {th }}$ rib along with lean color and skeletal ossification (USDA, 1997). Subprimals of the selected carcasses were vacuum packaged and transported to the Gordon W. Davis Meat Laboratory where they were stored at 2 to $4{ }^{\circ} \mathrm{C}$ in the absence of light, and aged to 21 days postmortem prior to fabrication. Steak cutting, selection and cooking followed Meat Standards Australia (MSA) protocols (Watson, Gee, Polkinghorne, \& Porter, 2008). The muscles, Longissimus lumborum, Psoas major, Semimembranosus, and Gluteus medius (from striploin, tenderloin, inside round, and top sirloin subprimals, respectively) were denuded of all epimysium and fat.

Semimembranosus and Gluteus medius muscles were sectioned parallel with muscle fibers in order to allow steak cutting across the grain. Longissimus lumborum and Psoas major muscles were cut perpendicular to the length of each muscle having some grain angle, specifically in 
92 Longissimus lumborum steaks. All muscles were cut into $25 \mathrm{~mm}$ thick steaks approximately 10

$93 \mathrm{~cm} \times 5 \mathrm{~cm}$ in length and width, starting at the anterior end of the muscle or muscle section. The

94 resulting steaks were individually wrapped in plastic, vacuum packed in sets of five, identified

95 with a unique sample code and frozen $\left(-20^{\circ} \mathrm{C}\right)$. Frozen wrapped steaks were later sorted into

96 predetermined groups of 10 steaks, each being a single steak from 10 of the original sample

97 codes, representing a cooking round and re-vacuum packaged. This re-sorting was determined by

98 MSA protocols and related software routines to produce a six by six latin square presentational

99 order in which six test products were arranged so that each product was cooked and served an

100 equal number of times in each of six presentational orders (serving rounds two to seven) and

101 served before and after each other product an equal number of times. The first cooking and

102 serving round utilized a common presumed mid position "starter" served to all consumers. The

103 five individual steaks from each original sample were placed and served in five different rounds

104 to counter potential order effects.

105 2.2. Consumer palatability scores

106 Consumer palatability scoring was conducted in accordance with MSA protocols (Watson et 107 al., 2008). Steaks were thawed at 2 to $5^{\circ} \mathrm{C}$ for 24 hours prior to cooking. All steaks were cooked

108 using a Silex clamshell grill (model S-143k, Silex Grills Australia Pty. Ltd., Marrickville,

109 Australia). Plate surface temperature was set at $225^{\circ} \mathrm{C}$ and preheated $45 \mathrm{~min}$ prior to panels.

110 Each panel session was conducted using a count up timer and timed schedule. Each session

111 commenced with cooking of a warm up load to stabilize grill recovery temperatures prior to the

112 seven cooking rounds. Loading and unloading of both the warm up and subsequent six test

113 rounds was conducted in accordance with the time schedule as was serving of test samples.

114 During panels steaks were loaded on the grill in seven designated groups (rounds) of 10. The 
115 grill surface was scraped, cleaned and greased with non-flavored cooking spray (Pam ${ }^{\circledR}$ Original 116 Non-Stick Cooking Spray, ConAgra Foods, Inc., Omaha, NE, USA) between rounds. Steaks

117 were cooked 5 min with the grill closed, removed at the designated time and allowed to rest for 3 118 min. During resting three $1.27 \mathrm{~cm}$ diameter cores were removed across the center line of selected 119 steaks for volatile analysis by coring through the thickness of steaks perpendicular to cut surfaces 120 in order to produce cores of similar volume (approximately $2.5 \mathrm{~cm}$ in length and $1.27 \mathrm{~cm}$ in 121 diameter). After the resting period each steak was cut into two pieces (across the cored section), 122 and immediately served to two designated consumers.

123 Sessions were conducted in evenings by paid consumers $(n=278)$ recruited from Lubbock, 124 TX, USA and the surrounding area. Consumers were recruited from various community and 125 charity groups with the group paid for attendance as a fund raiser rather than paying individuals. 126 Consumers were screened to include only regular beef eaters that preferred "medium doneness." 127 Each consumer was assigned to a numbered booth containing a ballot, plastic knife, plastic 128 fork, toothpicks, napkins, a cup of water, an expectorant cup, and between sample palate 129 cleansers (a 10\% apple juice, 90\% water solution and unsalted crackers). Panelists were verbally 130 instructed to utilize the provided plastic utensils to cut steaks into bite sizes similar to their 131 normal beef consumption habits.

132 Groups of 20 consumers each evaluated seven steaks, the first a standard "starter", chosen to 133 be of a mid-range quality, to acclimate consumers, followed by one from each of six product 134 groups encompassing a wide quality range derived from multiple muscles and USDA quality 135 grade. Each steak was rated on a 100-mm continuous line scale for tenderness, juiciness, flavor 136 liking and overall liking. On the scale, zero was verbally anchored as "not tender," "not juicy," 137 "dislike flavor extremely," and "dislike overall extremely." Conversely, 100 was verbally 
138 anchored as "very tender", "very juicy", "like flavor extremely", and "like overall extremely".

139 The MSA "MQ4" score was calculated as a weighted consumer score between one and 100,

140 using the standard MSA weightings of $30 \%$ for tenderness, flavor and overall liking and $10 \%$ for

141 juiciness.

142 2.3. Volatile compound evaluation

143 Volatile compound collection and gas chromatography-mass spectrometry (GC-MS) analysis 144 was conducted on selected steaks from those that were grilled and served to consumers during 145 each evening's consumer panel. Samples for volatile collection were collected from the selected 146 steaks, once removed from the grill, by obtaining three 1.27-cm diameter cores from the center 147 line of selected steaks during the resting period and before the remaining steak was cut into two 148 portions and served to two consumers. Each core was then cut again perpendicular to the muscle 149 fibers to enable the six pieces to be placed into a $15 \mathrm{~mL}$ clear glass vial (Supelco, Bellefonte, PA, 150 USA; preconditioned in an oven held at $\left.95^{\circ} \mathrm{C}\right)$. Preheated $\left(60^{\circ} \mathrm{C}\right)$ vials and screw caps 151 containing a polytetrafluoroethylene septum were then closed. The vial was then placed in a 65 $152{ }^{\circ} \mathrm{C}$ water bath (Thermo Scientific, Waltham, MA, USA) and allowed to equilibrate for $5 \mathrm{~min}$. 153 Volatiles were extracted by solid phase microextraction (SPME) using an $85 \mu \mathrm{m}$ film thickness 154 carboxen polydimethylsiloxane fiber in a manual SPME needle and holder (Supelco, Bellefonte, 155 PA, USA). Following equilibration, a SPME fiber was placed in the headspace above the sample 156 for 10 min. After collection, samples were withdrawn into the SPME needle, capped using an 157 inert GC septum (LB-2, Supelco, Bellefonte, PA, USA) and placed in a glass test tube with a 158 PTFE-lined lid (all preheated in an oven at $95^{\circ} \mathrm{C}$ ). The SPME fibers with collected volatiles 159 were held at 2 to $4{ }^{\circ} \mathrm{C}$ for up to a maximum of 24 hours, prior to analysis. Collection and holding 
160

161

was required as multiple volatile samples were collected simultaneously during consumer palatability scoring sessions.

An Agilent 6890 series GC (Agilent Technologies, Santa Clara, CA, USA) equipped with a 5975 MS detector (Agilent Technologies, Santa Clara, CA, USA) was used for separation and detection of volatile compounds. Extracted volatile compounds were desorbed from SPME fibers at the GC-MS inlet at $250{ }^{\circ} \mathrm{C}$ in splitless mode. Cryogenic focusing was conducted by placing the front of the GC column into a bed of dry ice (solid $\mathrm{CO}_{2}$ ). A loop of the front end of the column (approximately $100 \mathrm{~mm}$ ), between the injector and the remaining portion of the column, was placed into the dry ice for a period of $5 \mathrm{~min}$ prior to injection. The software program was then loaded and prepared to start and the SPME fiber was injected and desorbed for 5 min while the column remained in the dry ice. After 5 min the column was removed from the dry ice and the oven method was started. The SPME fiber remained exposed within the inlet for the first 3 min of the oven method to ensure all volatile compounds had been desorbed.

Compounds were separated using a BPX-5 capillary column $(25 \mathrm{~m} \times 0.32 \mathrm{~mm}, 0.25 \mu \mathrm{m}$ film thickness; SGE, Austin, TX, USA) with helium as the carrier gas at $1 \mathrm{~mL}$ per min. The oven method used included an initial 5 min at $35^{\circ} \mathrm{C}$, followed by an $8{ }^{\circ} \mathrm{C}$ per min ramp to $220^{\circ} \mathrm{C}$, then a $20^{\circ} \mathrm{C}$ per min ramp to $290{ }^{\circ} \mathrm{C}$, and finally a 5 min hold period at $290{ }^{\circ} \mathrm{C}$. The total run time was 37 min. The inlet was operated in splitless mode for the first 3 min followed by a 10:1 split. The MS detected ions within $33-500 \mathrm{~m} / \mathrm{z}$ range in the electron impact mode at $70 \mathrm{eV}$. Chromatography data was collected in the selective ion monitoring/scan mode (SIM/Scan; Agilent MSD Chemstation D.03.00.611 software, Agilent Technologies, Santa Clara, CA, USA). Ions were selected based on the presence of three primary ions from compounds of interest.

\subsection{Mass spectral identification of volatile compounds}


A solution of $n$-alkanes $\left(\mathrm{C}_{8}-\mathrm{C}_{22}\right.$, Supelco, Bellefonte, PA, USA; $\left.1 \mathrm{ng} / \mu \mathrm{L}\right)$ was run each day of analysis and linear retention indices (LRI) were calculated with reference to the $n$-alkanes (Goodner, 2008). The calculated LRI were used to determine retention times of compounds of interest. Volatile compound identity was confirmed by comparison of the ion fragmentation 187 patterns and the LRI with that of the authentic compounds. Three target ions were selected for

188 the comparisons between sample and standard runs with one quantitative ion and two qualifying 189 ions being selected for each compound of interest. A single-point external standard method was used for quantitation. External standard reference compounds (Sigma Aldrich, Saint Louis, MO, 191 USA) were delivered in solutions $(1 \mathrm{ng} / \mu \mathrm{l})$ of pentane (later eluding compounds) or toluene

192 (early eluting compounds) in splitless-mode. Quantitative ion abundances of sample runs were 193 compared with quantitative ion abundances of standard runs of known concentration.

194 Compounds not detected in sample runs were treated as zero

\section{2.5. Proximate Analysis}

196 Proximate analysis of raw steaks was conducted by an AOAC official method (2007.04;

197 Anderson, 2007) using a near infrared spectrophotometer (FoodScan, FOSS NIRsystems, Inc., 198 Laurel, MD, USA). Chemical percentages of fat, moisture, protein, and total collagen were 199 determined for each muscle within each USDA quality grade, as described previously (O'Quinn 200 et al., 2011).

\section{2.6. Statistical analysis}

202 Statistical analysis was conducted based on a generalized linear mixed model, using the Proc 203 Glimmix procedure of SAS (Version 9.3, Cary, NC). Two-way analysis of variance was used to 204 evaluate the fixed effects of USDA quality grade, beef muscle and their interaction. Steak was 205 the experimental unit. Panel session, serving round, and consumer were each treated as random 
206 effects in the model. Differences were considered significant at $P<0.05$. The CORR procedure

207 of SAS was used to determine Pearson correlation coefficients. Principal component (PC)

208 analysis was performed on volatile compounds using PROC FACTOR of SAS (v.9.3, Cary, NC).

209 Three principal components, PC1, PC2 and PC3 were retained to determine treatment scores and 210 correlation coefficients with consumer palatability scores and proximate data. The treatment PC

211 scores and correlation coefficients were plotted together $(\mathrm{x}$ coordinate $=\mathrm{PC} 1 ; \mathrm{y}$ coordinate $=$

212 PC2 or PC3 correlation coefficients) to evaluate relationships.

\section{3. Results and Discussion}

214 3.1. Chemical fat, collagen, moisture, and protein

215 Proximate analysis was conducted for steaks from subprimals for which consumer and

216 volatile flavor compound evaluations were obtained (Table 1). It is important to note that the

217 samples for inclusion in this experiment were selected to give clear differences in the chemical

218 fat content of the Longissimus lumborum between grades. Therefore, these data do not represent

219 a random selection of samples from these USDA quality grades and are recorded to assist with

220 the explanation of consumer and flavor analyses.

221 Percent chemical fat, collagen and moisture showed an interaction between USDA quality

222 grade and muscle $(P<0.001,0.01,0.001$, respectively; Table 1). In Longissimus lumborum

223 steaks the chemical fat percentages of the various quality grades were similar to previous

224 findings (Emerson, Woerner, Belk, \& Tatum, 2013). As quality grade increased, fat content

225 increased while moisture content decreased, as demonstrated in numerous previous studies (Hunt 226 et al., 2014; Von Seggern, Calkins, Johnson, Brickler, \& Gwartney, 2005; Brackebush, McKeith,

227 Carr, \& McLaren, 1991; Romans, Tuma, \& Tucker, 1965). The interaction between grade and 228 muscle highlighted the fact that the relationship between grade and fat content differs markedly 
among muscles. Intramuscular fat levels in Psoas major, Gluteus medius and Semimembranosus follow a similar pattern to the Longissimus samples, but the differences were much less distinct, with most difference occurring between Prime and Upper 2/3 Choice compared with the Low Choice, Select and Standard grades. As expected, an opposite pattern of effects was observed for percent moisture content, though the differences between muscles and grades were much smaller. Other researchers have also reported that moisture and fat content of beef muscles vary with quality grade (Hunt et al., 2014; Von Seggern et al., 2005).

There was no interaction for percent protein $(P>0.05)$, but there were differences due to muscles $(P<0.01)$ and grade $(P<0.05)$, similar to Hunt et al $(2014)$. As expected, these differences, again small, follow the pattern for the percent moisture and mirror that for percent fat (Table 1). This trend reflects results reported by previous works (Hunt et al., 2014; Brakebusch et al., 1991; Romans et al., 1965).

An interaction was present between grade and muscle for percent collagen $(P<0.01)$, with levels increasing in higher grades of Longissimus lumborum but unaffected by grade in Psoas major. Prost et al. (1975) has previously reported that percent collagen of the Psoas major is unaffected by grade. Variation in percent collagen between muscles is well documented (Von Seggern et al., 2005; McKeith, De Vol, Miles, Bechtel, \& Carr, 1985; Prost, Pelczynska, \& Kotolua, 1975). The effect of quality grade on percent collagen is less clear and often dependent on muscle (Von Seggern et al., 2005), as found in this study.

\subsection{Consumer palatability scores}

Consumer evaluations of tenderness, juiciness, flavor liking, and overall liking of beef steaks from four muscles and five USDA quality grades are displayed in Table 2, along with the composite MQ4 value. The results show significant interactions between muscle and grade $(P<$ 
252 0.05) for all attributes except tenderness. Surprisingly, USDA quality grade had no effect $(P>$

$2530.05)$ on consumer tenderness ratings and there was no interaction between muscle and grade $(P$

$254>0.05$ ). However, as expected from previous reports (Browning, Huffman, Egbert, \& Jungst,

255 1991; Christensen, Johnson, West, Marchall, \& Hargrove, 1991; McKeith et al., 1985),

256 tenderness differed $(P<0.05)$ between all the muscles (Table 2$)$, with mean scores ranging from

25738 for Semimembranosus to 89 for Psoas major.

258 Juiciness was determined by consumers to be greatest among Psoas major steaks from Prime,

259 Upper 2/3 Choice, Select, and Standard quality grades along with Prime Longissimus lumborum

260 steaks $(P<0.05 ;$ Table 2). Interestingly, Low Choice Psoas major and Low Choice

261 Semimembranosus steaks received lower scores than the rest of the quality grades for these

262 muscles, but the same effect was not observed for Gluteus medius and Longissimus lumborum

263 muscles. Thus, juiciness scores differed between muscles and were generally greater in Prime

264 and Upper 2/3 Choice grades. These are the same grades that had greater percent fat supporting

265 the documented belief that percent fat is related to juiciness (Lorenzen et al., 1999; Lorenzen et

266 al., 2003; Savell, Cross, \& Smith, 1986; Smith et al.1984). Flavor liking scores followed similar

267 trends (Table 2) to juiciness where an interaction $(P<0.05)$ for flavor liking was due to lower

268 flavor liking scores within Psoas major and Semimembranosus Low Choice grade receiving

269 lower scores than expected.

270 The MSA MQ4 value, as previously described, assessed meat eating quality based on

271 weighted calculations. This value has been shown to predict consumer satisfaction and avoids the

272 difficulty consumers have in distinguishing between attributes (Watson et al., 2008). In this data

273 the MQ4 values followed similar trends as overall liking and flavor liking (Table 2). 
Generally, the effect of USDA quality grade on juiciness, flavor liking, overall liking, and

275 MQ4 was found to be dependent on muscle (Table 2). For most muscles, these attributes did not

276 show consistent increases in consumer score with increasing quality grade. Specifically, the

277 Longissimus lumborum muscle was the only muscle possessing a linear ranking with quality

278 grade for juiciness, flavor liking, overall liking, and MQ4. This is likely the effect of fat level

279 within the different muscles. The maximum difference in fat content between USDA Prime

280 Longissimus lumborum and USDA Standard Longissimus lumborum was close to 12\% (where

281 samples were selected on percent fat), whereas the range in percent fat was only $5.2 \%$ in the

282 Psoas major, 5.5\% in the Gluteus medius, and 4.9\% in the Semimembranosus (Table 1).

283 Additionally, USDA quality grade did not have an effect $(P>0.05)$ on fat content for muscles

284 other than the Longissimus lumborum, especially for the lowest three quality grade treatments

285 (Table 2).

286 3.3. Volatile compounds

287 A total of 26 volatile compounds representing pathways of cooked beef flavor development

288 (e.g., thermal oxidation of lipids, Maillard reaction) were selected and quantified. Table 3 shows

289 the mean quantities of volatiles collected from different muscles while Table 4 presents the

290 quantities for those volatile compounds which showed a significant interaction $(P<0.05)$. None

291 of the compounds differed $(P>0.05)$ due to quality grade as a first order effect. Some of the

292 interactions were influenced by particularly low quantities detected for one muscle/grade

293 interaction, especially for some Psoas major samples.

294 Five compounds (2,3-butanedione, heptane, 3-hydroxy-2-butanone, octane, and methyl

295 pyrazine) differed $(P<0.05)$ between muscles independent of quality grade (Table 3$)$. The

296 alkanes, heptane and octane, were found in greatest $(P<0.05)$ quantities from $P$ soas major 
297

298

299

300

301

302

303

304

305

306

307

308

309

310

311

312

313

314

315

316

317

318

319

steaks while being similar $(P>0.05)$ to Gluteus medius and Semimembranosus steaks but differing $(P<0.05)$ from Longissimus lumborum steaks (Table 3). Alkanes are formed from the oxidation of long-chain fatty acids (Mottram, 1991). In this study, alkanes did not appear to be related to percent fat.

The ketones, 3-hydroxy-2-butanone and 2,3-butanedone were both present in greatest $(P<$ 0.05) abundance in the headspace of Gluteus medius and Semimembranosus steaks compared with Longissimus lumborum and Psoas major steaks (Table 3). These compounds can arise from the 2,3-enolisation pathways which form part of the Maillard reaction (Hurrell, 1982). This could arise from elevated levels of reducing sugars and amino acids or from a higher $\mathrm{pH}$, which favors 2,3-enolisation. Other Maillard products are not similarly affected (Table 3) so the role of $\mathrm{pH}$ within muscles may be worthy of further investigation.

Methyl pyrazine was found in the greatest $(P<0.05)$ abundance among Longissimus lumborum steaks compared with Psoas major and Semimembranosus, while Gluteus medius steaks were intermediate and similar $(P>0.05)$ to all other muscles (Table 3). Similar trends for other pyrazines were not significant $(P>0.05$; Table 4$)$. Nitrogen-containing pyrazines are known to be some of the final products of the Maillard reaction (Back, 2007). Although they occur at lower abundances, compared with lipid degradation volatile compounds, these compounds have low odor thresholds which contribute roasted flavors (Buttery \& Ling, 1997).

Certain aldehydes have been shown to be the result of Strecker degradation of amino acids. Degradation of alanine, isoleucine, leucine, methionine, phenylalanine, and valine leads to the development of acetaldehyde, 2-methylbutanal, 3-methylbutanal, methional, and phenylacetaldehyde (Cerny, 2007). Benzaldehyde, is another volatile compound potentially resulting from the Strecker degradation of the amino acid phenylglycine (MacLeod, \& Ames, 
1987; Mottram, \& Edwards, 1983). However, as phenylglycine is not an amino acid which

321

322 323 occurs in muscle, a different mechanism of formation must be responsible in this case. In our study, benzaldehyde was found to be greater $(P<0.05)$ in Psoas major, Gluteus medius, and Semimembranosus steaks.

Interactions $(P<0.05)$ were found between muscle and USDA grade for seven compounds (acetaldehyde, 2-propanone, dimethyl sulfide, hexanal, benzaldehyde, octanal, and nonanal; Table 4). The effect of quality grade on the $n$-aldehydes, octanal, and nonanal, depended on muscle (Table 4). In the case of Longissimus lumborum and Psoas major, there was a clear and significant increase in quantities detected with a decrease in grade. Interestingly the fat content of these muscles decreased with quality grade (Table 1). Formation of aldehydes occurs in cooked meat through the thermal oxidation of fatty acids such as oleic, linoleic, and linolenic acid (Cerny, 2007). Each of these aldehydes have previously been identified in beef odor (Mottram, 1991).

Among volatile compounds found to have interactions between USDA quality grade and muscle (Table 4), acetaldehyde, 2-propanone and dimethyl sulfide were all found to be greatest among Upper $2 / 3$ Choice Psoas major steaks $(P<0.05)$. Interestingly, Upper $2 / 3$ Choice Psoas major steaks received the greatest score for flavor liking by consumers (Table 2). Sulfurcontaining compounds, including dimethyl sulfide, contribute to meaty flavor notes (Gasser \& Grosch, 1990). The sum of sulfur-containing compounds (dimethyl sulfide, dimethyl disulfide, methanethiol, and methional) were collectively found to be greatest $(P<0.05)$ among Psoas major steaks.

Overall, these data indicate that the pattern of volatile compounds differs between muscles. Psoas major was characterized by greater levels of the sulfur-containing thiols and sulfides; 
343 these and other sulfur-containing compounds are known to contribute to the meaty and roasted

344 characteristics of beef flavor (Mottram, 1991). It is of interest that Psoas major steaks

345 consistently received the greatest scores for flavor liking though relationships between the

346 attributes may mean that this score was influenced by tenderness (Table 2). This phenomenon

347 has been described as a halo-effect where one favorable attribute influences consumer's

348 perception of other attributes (Roeber, et al., 2000). As previously described tenderness is often

349 considered to be the most influential beef palatability attribute and this may have some impact on

350 flavor liking in this study within the notoriously tender Psoas major muscle. Longissimus

351 lumborum steaks tended to give greater amounts of pyrazines (Table 3), known to contribute to

352 roasted and nutty characteristics (Mottram, 1991), but lower concentrations of benzaldehyde and

353 short chain ketones. Gluteus medius and Semimembranosus steaks gave high levels of some short

354 chain ketones known to participate in a range of flavor forming reactions and tended to give

355 more $n$-aldehydes, though there was considerable variability between USDA grades (Table 4).

356 These differences would be expected to influence and explain differences in perceived flavor

357 quality between the different muscles.

\section{3.4. Correlations}

Pearson correlations between proximate data and consumer palatability scores are

360 displayed in Table 5. As expected, moisture was inversely related with chemical fat $(\mathrm{r}=-0.97 ; P$

$361<0.001)$. This inverse relationship between moisture and fat content in multiple beef muscles is

362 very similar to previous work, where a similarly highly significant correlation $(\mathrm{r}=-0.92)$ was

363 found (Jeremiah, Dugan, Aalhus, \& Gibson, 2002).

There is an apparent correlation between increased chemical fat and increased collagen

$365(P<0.001)$. Previously, accumulation of collagen during animal physiological maturation was 
366

367

368

369

370

371

372

373

374

375

376

377

378

379

380

381

382

383

384

385

386

387

388

documented to impact palatability, specifically tenderness (Berry, Smith, \& Carpenter, 1974;

Breidenstein, Cooper, Cassens, Evans, \& Bray, 1968; Romans et al., 1965). However, in this

study similarly young 'A' maturity carcasses were selected for all grades. A weak positive correlation was observed between collagen and juiciness, flavor liking, and overall liking $(P<$

0.05), but not tenderness (Table 5).It is difficult to propose any direct causative link between more collagen and higher consumer scores.

Overall liking was greatly correlated with flavor liking, juiciness and tenderness $(P<0.001$;

Table 5) indicating that consumers find it difficult to differentiate fully between attributes.

Percent fat was correlated with overall liking, tenderness, juiciness, and flavor liking $(P<0.001)$, as expected from previous work (McKeith et al., 1985; Tatum, Smith, Berry, Murphey,

Williams, \& Carpenter, 1980). There was also a tendency for negative correlations of $n$ aldehydes with flavor liking, overall liking, and percent fat (Table 6).

Negative correlations of long chain $n$-aldehydes (octanal and decanal) with percent fat (Table 6) may be due to the retention of volatile compounds by fat, delaying flavor release as described previously (Farmer, Hagan, Oltra, Devlin, \& Gordon, 2013; Chevance et al., 2000; Chevance \& Farmer, 1999). However, this effect was not apparent for other compounds or compound groups, which showed no significant correlations with percent fat $(P>0.05$; data not tabulated). Instead, these results may indicate a greater potential for oxidation of unsaturated fatty acids of the polar lipid fraction within beef steaks having low total percent fat. Within beef with a lower total fat content, a greater proportion of the fat includes polar lipids (Wood et al., 2008). Polar lipids are known to be more susceptible to oxidation (Mottram, 1998). Previously, volatile compounds associated with lipid oxidation were increased up to 4-fold in response to increased proportions of polyunsaturated fatty acids (Elmore, Mottram, Enser, \& Wood, 1999). 


\subsection{Principal component analysis}

Principal component analysis (PCA) was conducted in order to explore relationships between multiple volatile compounds and muscles of different quality grades. Volatile compounds were used to determine principal components (PCs). When PCA was conducted for all grade and muscle treatments PC1 explained 39.8\%, PC2 explained $29.4 \%$, and PC3 explained $20.8 \%$ of the variation associated with volatile compounds (Figures 1 and 2). Plots revealed that PC1 separated Upper 2/3 Choice Psoas major from most of the samples on the basis of increased quantities of many of the Maillard products and reduced quantities of lipid oxidation products. Secondly, PC2 tended to separate Longissimus lumborum steaks from many of the other muscles and was associated with an overall lack of volatiles. Principle Component 3 separated Psoas major steaks of all grades from many of the remaining samples, with the Psoas major being associated with greater quantities of sulfur-containing Maillard products.

Volatile compounds segregated into clusters of similar compound classes (Figures 1 and 2). Pyrazines, Strecker aldehydes, and sulfur compounds were found to be positively related with PC1, while lipid oxidation products, aldehydes, ketones, and alkanes were clustered together and negatively related with PC1. Figure 2 revealed that PC3 separated the treatments on the basis of different groups of Maillard products. This collinear divergence of compound groups may make it possible to use related compounds as "markers" for flavor compounds of greater odor significance which are difficult to detect. Most volatile compounds were located on the positive side of PC2 while percent fat was on the negative side, a similar finding was reported in a recent work (Farmer et al., 2013) where lower fat content beef was related with greater quantities of volatile compounds. It was suggested by Farmer et al., (2013) that lower intramuscular fat content leads to increases in volatile compounds, due to the solubility of volatile aroma 
412 compounds in lipids, as previously observed in frankfurters (Chevance \& Farmer, 1999;

413 Chevance et al., 2000).

414 Longissimus lumborum showed an association with chemical fat content and an absence of

415 volatile compounds compared with other muscles regardless of quality grade (Figure 1). Upper

416 2/3 Choice Psoas major, which diverted from the remaining treatments was associated with

417 groupings of sulfur-containing compounds and Maillard products and was greatly separated from

$418 n$-aldehydes. The data in Table 4 show that this treatment gave unusually (and consistently) high

419 levels of acetaldehyde, 2-propanone and sulfur-containing compounds.

420 Figure 2 confirms that Maillard products are closely associated with flavor development

421 (Mottram, 1998) and in this study flavor liking. More specifically, sulfur-compounds were

422 greatly associated with flavor liking. This may reflect the importance of these and other sulfur-

423 containing compounds for aspects of beef flavor.

\section{4. Conclusions}

425 The results of this study indicate that there is potential to gain understanding of flavor

426 differences between beef muscles through the analysis of volatile flavor compounds in

427 association with palatability and chemical measurements. Similar to previous studies USDA

428 quality grade affected consumer flavor and overall liking dependent on muscle. Beef muscle type

429 greatly influenced volatile compounds. Some volatile compounds were negatively correlated

430 with percent fat, while others were not related to fat content. Volatile compounds from similar

431 compound classes and from the same pathways of formation behaved, similarly, with Maillard

432 products being most closely related with flavor liking. This clear relationship between

433 palatability scores and volatile compound classes suggests that differences in the pattern of

434 volatile compounds between muscles may play a valuable role in explaining consumer liking. 


\section{References}

Adhikari, K., \& Chambers IV, E. (2010). Differentiation of beef flavor across muscles and quality grades (Phase I). Centennial, CO: National Cattlemens’ Beef Association.

Anderson, S. (2007). Determination of fat, moisture, and protein in meat and meat products using the FOSS, FoodScan Near-Infrared Spectrophotometer with FOSS Artificial Neural Network Calibration Model and Associated Database: Collaborative study. Journal of AOAC International, 90, 1073-1083.

Back, H. H. (2007). Process flavors. In L. M. L. Nollet (Eds) Handbook of Meat, Poultry, \& Seafood Quality. (pp 311-326). Ames, Iowa: Blackwell Publishing.

Behrends, J. M., Goodson, K. J., Koohmaraie, M., Shackelford, S. D., Wheeler, T. L., Morgan, W. W., Reagan, J. O., Gwartney, B. L., Wise, J. W., \& Savell, J. W. (2005a). Beef customer satisfaction: Factors affecting consumer evaluations of calcium chlorideinjected top sirloin steaks when given instructions for preparation. Journal of Animal Science, 83(12), 2869-2875.

Behrends, J. M., Goodson, K. J., Koohmaraie, M., Shackelford, S. D., Wheeler, T. L., Morgan, W. W., Reagan, J. O., Gwartney, B. L., Wise, J. W., \& Savell, J. W. (2005b). Beef customer satisfaction: USDA quality grade and marination effects on consumer evaluations of top round steaks. Journal of Animal Science, 83(3), 662-670.

Berry, B. W., Smith, G. C., \& Carpenter, Z. L. (1974). Beef carcass maturity indicators and palatability attributes. Journal of Animal Science, 38, 507-514.

Brackebusch, S. A., McKeith, F. K., Carr, T. R., \& McLaren, D. G. (1991). Relationship between longissimus composition and the composition of the other major muscles of the beef carcass. Journal of Animal Science 69, 631-640. 
Breidenstein, B. B., Cooper, C. C., Cassens, R. G., Evans, G., \& Bray, R. W. (1968). Influence of marbling and maturity on the palatability of beef muscle. 1. Chemical and organoleptic considerations. Journal of Animal Science, 27, 1532-1541.

Browning, M. A., Huffman, D. A., Egbert, W. R., \& Jungst, S. B. (1990). Physical and compositional characteristics of beef carcasses selected for leanness. Journal of Food Science, 55, 9-14.

Buttery, R. G., \& Ling, L. C. (1997). 2-Ethyl-3,5-dimethylpyrazine and 2-ethyl-3,6dimethylpyrazine odor thresholds in water solution. Lebensmittel Wissenschaft und Technologie, 30, 109-110.

Calkins, C. R., \& Hodgen, J. M. (2007). A fresh look at meat flavor. Meat Science, 77, 63-80.

Cerny, C. (2007). Sensory evaluation of beef flavor. In L. M. L. Nollet (Eds) Handbook of Meat, Poultry, \& Seafood Quality. (pp 311-326). Ames, Iowa: Blackwell Publishing.

Cerny, C., \& Grosch, W. (1992). Evaluation of potent odorants in roasted beef by aroma- extract dilution analysis. Zeitschrift fur Lebensmittel Untersuchung und Forschung, 194, 322325.

Chevance, F. F. V., \& Farmer, L. J. (1999). Release of volatile odor compounds from full and low-fat frankfurters. Journal of Agricultural and Food Chemistry, 47, 5161-5168

Chevance, F. F. V., Farmer, L. J., Desmond, E. M., Novelli, E., Troy, D. J., \& Chizzolini, R. (2000). Effects of some fat replacers on the release of volatile aroma compounds from low-fat meat products. Journal of Agricultural and Food Chemistry, 48, 3476-3484.

Christensen, K. L., Johnson, D. D., West, R. L., Marshall, T. T., \& Hargrove, D. D. (1991). The effect of breed of sire and age at feeding on muscle tenderness in the beef chuck. Journal of Animal Science, 69, 3673-3678. 
Cross, H. R., Berry, B. W., \& Wells, L. H. (1980). Effects of fat level and source on the chemical, sensory, and cooking properties of ground beef patties. Journal of Food Science, 45(4), 791-794.

Elmore, J. S., Mottram, D. S., Enser, M., \& Wood, J. D. (1999). Effect of the polyunsaturated fatty acid composition of beef muscle on the profile of aroma volatiles. Journal of Agricultural and Food Chemistry, 47(4), 1619-1625.

Emerson, M. R., Woerner, D. R., Belk, K. E., \& Tatum, J. D. (2013). Effectiveness of USDA instrument-based marbling measurements for categorizing beef carcasses according to differences in longissimus muscle sensory attributes. Journal of Animal Science, 91, 1024-1034.

Farmer, L. J., Hagan, T. D. J., Oltra, O. R., Devlin, Y. and Gordon, A. W. (2013). Relating beef aroma compounds to flavour precursors and other measures of quality. Proceedings of the 10th Wartburg Symposium on Flavor Chemistry and Biology, April 2013 (in press).

Farmer, L. J., \& Patterson, R. L. S. (1991). Compounds contributing to meat flavour. Food Chemistry, 40, 201-205.

Gasser, U., \& Grosch, W. (1988). Identification of volatile flavour compounds with high aroma values from cooked beef. Zeitschrift fur Lebensmittel Untersuchung und Forschung, 186, 489-494.

Gasser, U., \& Grosch, W. (1990). Primary odorants of chicken broth. A comparative study with meat broths from cow and ox. Zeitschrift fur Lebensmittel Untersuchung und Forschung, 190, 3-8.

Goodner, K. L. (2008). Practical retention index models of OV-101, DB-1, DB-5, and DB-Wax for flavor and fragrance compounds. LWT-Food Science and Technology, 41, 951-958. 
Goodson, K. J., Morgan, W. W., Reagan, J. O., Gwartney, B. L., Courington, S. M., Wise, J. W., \& Savell, J. W. (2002). Beef customer satisfaction: factors affecting consumer evaluations of clod steaks. Journal of Animal Science, 80(2), 401-408.

Hodge, J. E. (1953). Chemistry of browning reactions in model systems. Journal of Agricultural and Food Chemistry, 1, 928-943.

Hodgen, J. M., Cuppett, S. L., \& Calkins, C. R. (2006). Identification of off-flavor compounds in beef. In Proceedings of the American meat science association reciprocal meat conference, Champagne-Urbana, IL.

Huffman, K. L., Miller, M. F., Hoover, L. C., Wu, C. K., Brittin, H. C., \& Ramsey, C. B. (1996). Effect of beef tenderness on consumer satisfaction with steaks consumed in the home and restaurant. Journal of Animal Science, 74, 91-97.

Hunt, M. R., Garmyn, A. J., O’Quinn, T. G., Corbin, C. H., Legako, J. F., Rathmann, R. J., Brooks, J. C., \& Miller, M. F. (2014). Consumer assessment of beef palatability from four beef muscles from USDA Choice and Select graded carcasses. Meat Science, 98, 18.

Hurrell, R. F. (1982). Maillard reaction in flavour. In I. D. Morton \& A. J. Macleod (Eds.). Food Flavours. (pp. 399-437). Amsterdam: Elsevier.

Jeremiah, L. E., Dugan, M. E. R., Aalhus, J. L., \& Gibson, L. L. (2002). Assessment of the chemical and cooking properties of the major beef muscles and muscle groups. Meat Science, 65, 985-992.

Killinger, K. M., Calkins, C. R., Umberger, W. J., Feuz, D. M., \& Eskridge, K. M. (2004). Consumer sensory acceptance and value for beef steaks of similar tenderness, but differing in marbling level. Journal of Animal Science, 82(11), 3294-3301. 
Lorenzen, C. L., Miller, R. K., Taylor, J. F., Neely, T. R., Tatum, J. D., Wise, J. W., Buyck, M. J., Reagan, J. O., \& Savell, J. W. (2003). Beef customer satisfaction: Trained sensory panel ratings and Warner-Bratzler shear force values. Journal of Animal Science, 81, 143-149.

Lorenzen, C. L., Neely, T. R., Miller, R. K., Tatum, J. D., Wise, J. W., Taylor, J. F., Buyck, M. J., Reagan, J. O., \& Savell, J. W. (1999). Beef customer satisfaction: cooking method and degree of doneness effects on the top loin steak. Journal of Animal Science, 77, 637-644.

MacLeod, G., \& Ames, J. M. (1987). Effect of water on the production of cooked beef aroma compounds. Journal of Food Science, 52(1), 42-45.

McKeith, F. K., De Vol, D. L., Miles, R. S., Bechtel, P. J., \& Carr, T. R. (1985). Chemical and sensory properties of thirteen major beef muscles. Journal of Food Science, 50(4), 869872.

Miller, M. F., Carr, M. A., Ramsey, C. B., Crockett, K. L., \& Hoover, L. C. (2001). Consumer thresholds for establishing the value of beef tenderness. Journal of Animal Science, 79(12), 3062-3068.

Miller, M. F., Hoover, L. C., Cook, K. D., Guerra, A. L., Huffman, K. L., Tinney, K. S., Ramsey, C. B., Brittin, H. C., \& Huffman, L. M. (1995). Consumer acceptability of beef steak tenderness in the home and restaurant. Journal of Food Science, 60(5), 963-965.

Miller, R. K. (2010). Differntiation of beef flavor across muscles and quality grades (Phase II). Centennial, CO: National Cattlemens' Beef Association.

Mottram, D. S. (1991). Meat. In H. Maarse (Eds.), Volatile Compounds in Food and Beverages. (pp. 107-177). New York: Marcel Dekker, Inc. 
Mottram, D. S. (1998). Flavour formation in meat and meat products: a review, Food Chemistry, 62(4), 415-424.

Mottram, D. S., \& Edwards, R. A. (1983). The role of triglycerides and phospholipids in the aroma of cooked beef. Journal of the Science of Food and Agriculture, 34(5), 517-522.

Mottram, D. S., Edwards, R. A., \& Macfie, J. H. H. (1982). A comparison of the flavour volatiles from cooked beef and pork meat systems. Journal of the Science of Food and Agriculture, 33(9), 934-944.

NAMP. (2010). The meat buyer's guide (6th ed.). North American Meat Processors Association, Reston, VA.

O’Quinn, T. G., J. C. Brooks, R. J. Polkinghorne, A. J. Garmyn, B. J. Johnson, J. D. Starkey, R. J. Rathmann, and M. F. Miller. (2012). Consumer assessment of beef strip loin steaks of varying fat levels. Journal of Animal Science, 90, 626-634.

Prost, E., Pelczynska, E., \& Kotolua, A. W. (1975) Quality characteristics of bovine meat. I. Content of connective tissues in relation to individual muscles, age and sex of animal and carcass quality grade. Journal of animal Science, 41, 534-540.

Roeber, D. L., Cannell, R. C., Belk, K. E., Miller, R. K., Tatum, J. D., \& Smith, G. C. (2000). Implant strategies during feeding: impact on carcass grades and consumer acceptability. Journal of Animal Science, 78(7), 1867-1874.

Romans, J. R., Tuma, H. J., \& Tucker, W. L. (1965). Influence of carcass maturity and marbling on the physical and chemical characteristics of beef 1. Palatability, fiber diameter and proximate analysis. Journal of Animal Science, 24, 681-685. 
Savell, J. W., Branson, R. E., Cross, H. R., Stiffler, D. M., Wise, J. W., Griffin, D. B., \& Smith, G. C. (1987). National consumer retail beef study: palatability evaluations of beef loin steaks that differed in marbling. Journal of Food Science, 52(3), 517-519.

Savell, J. W., Cross, H. R., \& Smith, G. C. (1986). Percentage of ether extractable fat and moisture content of beef longissimus muscle as related to USDA marbling score, Journal of Food Science, 51(3), 838-839.

Smith, G. C., Savell, J. W., Cross, H. R., \& Carpenter, Z. L. (1983). The relationship of USDA quality grade to beef flavor. Food Technology, 37(5), 233-238.

Smith, G. C., Carpenter, Z. L. Cross, H. R. Murphey, C. E. Abraham, H. C. Savell, J. W. Davis, G. W. Berry, B. W. \& Parrish Jr, F. C. (1984). Relationship of USDA marbling groups to palatability of cooked beef. Journal of Food Quality, 7, 289-308.

Tatum, J. D., Smith, G. C., Berry, B. W., Murphey, C. E., Williams, F. L., \& Carpenter, Z. L. (1980). Carcass characteristic, time on feed and cooked beef palatability attributes. Journal of Animal Science, 50, 833-840.

USDA. (1997). United States standards for grades of carcass beef. In: A. M. Service (Eds.). United States Department of Agriculture, Washington, DC.

Von Seggern, D. D., Calkings, C. R., Johnson, D. D., Brickler, J. E., \& Gwartney, B. L. (2005). Muscle profiling: Characterizing the muscles of the beef chuck and round. Meat Science, $71,39-51$.

Watson, R., Gee, A., Polkinghorne, R. \& Porter, M. (2008). Consumer assessment of eating quality - development of protocols for Meat Standards Australia (MSA) testing. Australian Journal of Experimental Agriculture, 48, 1360-1367. 
592 Wood, J. D., Enser, M., Fisher, A. V., Nute, G. R., Sheard, P. R., Richardson, R. I., Hughes, S. I., 593 \& Whittington, F. M. (2008). Fat deposition, fatty acid composition and meat quality: A review, Meat Science, 78, 343-358.

595 
Table 1. Proximate Data ${ }^{1}$ of raw beef steaks from five USDA Quality Grades and four muscles

\begin{tabular}{|c|c|c|c|c|c|}
\hline \multirow[b]{2}{*}{ USDA Quality Grade } & \multirow[b]{2}{*}{ Muscle } & \multicolumn{4}{|c|}{$\%$} \\
\hline & & Fat & Collagen & Moisture & Protein \\
\hline Prime & Psoas major & $8.1^{\mathrm{b}}$ & $1.8^{\text {cde }}$ & $69.5^{\mathrm{de}}$ & 21.2 \\
\hline Upper 2/3 Choice & Psoas major & $6.9^{\mathrm{bcd}}$ & $1.9^{\text {bcde }}$ & $70.3^{\text {cde }}$ & 21.4 \\
\hline Low Choice & Psoas major & $3.8^{\text {defghi }}$ & $1.7^{\mathrm{de}}$ & $73.1^{\mathrm{abc}}$ & 21.7 \\
\hline Select & Psoas major & $3.5^{\text {efghi }}$ & $1.9^{\mathrm{bcd}}$ & $72.5^{\mathrm{abc}}$ & 22.5 \\
\hline Standard & Psoas major & $2.9^{\text {fghij }}$ & $1.8^{\mathrm{de}}$ & $73.1^{a b c}$ & 22.1 \\
\hline Prime & Longissimus lumborum & $13.1^{\mathrm{a}}$ & $2.1^{\mathrm{ab}}$ & $64.0^{\mathrm{f}}$ & 21.7 \\
\hline Upper 2/3 Choice & Longissimus lumborum & $7.9^{\mathrm{b}}$ & $2.0^{\mathrm{abcd}}$ & $68.7^{\mathrm{e}}$ & 21.9 \\
\hline Low Choice & Longissimus lumborum & $4.5^{\mathrm{defg}}$ & $1.7^{\mathrm{de}}$ & $70.4^{\text {cde }}$ & 23.2 \\
\hline Select & Longissimus lumborum & $2.9^{\text {fghi }}$ & $1.7^{\mathrm{de}}$ & $71.3^{\mathrm{cd}}$ & 23.1 \\
\hline Standard & Longissimus lumborum & $1.3^{\mathrm{ij}}$ & $1.6^{\mathrm{e}}$ & $73.5^{\mathrm{ab}}$ & 23.3 \\
\hline Prime & Gluteus medius & $7.1^{\mathrm{bc}}$ & $2.3^{\mathrm{a}}$ & $69.0^{\mathrm{e}}$ & 21.7 \\
\hline Upper 2/3 Choice & Gluteus medius & $4.3^{\mathrm{defgh}}$ & $1.7^{\mathrm{de}}$ & $71.8^{\mathrm{bc}}$ & 21.8 \\
\hline Low Choice & Gluteus medius & $1.6^{\mathrm{ij}}$ & $1.6^{\mathrm{e}}$ & $72.4^{\mathrm{abc}}$ & 23.3 \\
\hline Select & Gluteus medius & $2.9^{\text {fghij }}$ & $1.9^{\mathrm{bcd}}$ & $71.8^{\mathrm{bc}}$ & 22.9 \\
\hline Standard & Gluteus medius & $2.6^{\text {gghij }}$ & $1.9^{\mathrm{bcd}}$ & $72.3^{\mathrm{abc}}$ & 22.9 \\
\hline Prime & Semimembranosus & $5.6^{\text {cde }}$ & $1.9^{\mathrm{bcd}}$ & $70.6^{\text {cde }}$ & 22.5 \\
\hline Upper 2/3 Choice & Semimembranosus & $5.0^{\text {cdef }}$ & $2.1^{\mathrm{abc}}$ & $71.4^{\mathrm{cd}}$ & 21.8 \\
\hline Low Choice & Semimembranosus & $2.0^{\text {hij }}$ & $1.8^{\text {cde }}$ & $72.8^{\mathrm{abc}}$ & 23.2 \\
\hline Select & Semimembranosus & $2.5^{\text {ghij }}$ & $1.9^{\mathrm{bcd}}$ & $72.3^{\mathrm{abc}}$ & 23.2 \\
\hline Standard & Semimembranosus & $0.7^{\mathrm{j}}$ & $1.6^{\mathrm{e}}$ & $74.1^{\mathrm{a}}$ & 23.1 \\
\hline Std. Error & & 1.5 & 0.2 & 1.5 & 0.8 \\
\hline \multirow[t]{7}{*}{$P$ value } & & $<0.001$ & 0.004 & $<0.001$ & 0.809 \\
\hline & Psoas Major & 5.0 & 1.8 & 71.7 & $21.8^{\mathrm{b}}$ \\
\hline & Longissimus lumborum & 5.9 & 1.8 & 69.6 & $22.7^{\mathrm{a}}$ \\
\hline & Gluteus medius & 3.7 & 1.9 & 71.5 & $22.5^{\mathrm{a}}$ \\
\hline & Semimembranosus & 3.2 & 1.9 & 72.2 & $22.8^{\mathrm{a}}$ \\
\hline & Std. Error & 0.4 & 0.1 & 0.4 & 0.2 \\
\hline & $P$ value & $<0.001$ & 0.766 & $<0.001$ & 0.006 \\
\hline Prime & & 8.5 & 2.0 & 68.3 & $21.8^{\mathrm{b}}$ \\
\hline Upper 2/3 Choice & & 6.0 & 1.9 & 70.5 & $21.7^{\mathrm{b}}$ \\
\hline Low Choice & & 2.9 & 1.7 & 72.1 & $22.9^{\mathrm{a}}$ \\
\hline Select & & 2.9 & 1.9 & 71.9 & $22.9^{\mathrm{a}}$ \\
\hline Standard & & 1.9 & 1.7 & 73.2 & $22.9^{\mathrm{a}}$ \\
\hline Std. Error & & 0.5 & 0.1 & 0.5 & 0.2 \\
\hline$P$ value & & $<0.001$ & 0.019 & $<0.001$ & 0.028 \\
\hline
\end{tabular}

$596 \quad$ abcdefghij Means within a column lacking a common superscript differ $(P<0.05)$.

$597{ }^{1}$ Chemical percentages of fat, moisture, protein, and collagen determined of raw steaks by

598 AOAC official method (2007.04; Anderson, 2007) 
Table 2. Consumer palatability scores ${ }^{1}$ of grilled beef steaks from five USDA Quality Grades and four muscles

\begin{tabular}{|c|c|c|c|c|c|c|}
\hline $\begin{array}{l}\text { USDA Quality } \\
\text { Grade }\end{array}$ & Muscle & Tenderness & Juiciness & $\begin{array}{l}\text { Flavor } \\
\text { Liking }\end{array}$ & $\begin{array}{l}\text { Overall } \\
\text { Liking }\end{array}$ & MQ4 \\
\hline Prime & Psoas major & 94.1 & $85.9^{\mathrm{a}}$ & $84.8^{\mathrm{a}}$ & $89.1^{\mathrm{a}}$ & $89.7^{\mathrm{a}}$ \\
\hline Upper 2/3 Choice & Psoas major & 90.2 & $86.3^{\mathrm{a}}$ & $86.1^{\mathrm{a}}$ & $88.1^{\mathrm{ab}}$ & $84.9^{\mathrm{abc}}$ \\
\hline Low Choice & Psoas major & 81.4 & $55.5^{\mathrm{efg}}$ & $67.9^{\text {abcde }}$ & $67.1^{\mathrm{bcd}}$ & $71.5^{\text {bcde }}$ \\
\hline Select & Psoas major & 94.1 & $73.7^{\mathrm{abcd}}$ & $84.9^{\mathrm{a}}$ & $86.3^{\mathrm{ab}}$ & $87.4^{\mathrm{ab}}$ \\
\hline Standard & Psoas major & 90.1 & $81.4^{\mathrm{ab}}$ & $75.7^{\mathrm{ab}}$ & $82.7^{\mathrm{ab}}$ & $82.6^{\text {abcd }}$ \\
\hline Prime & Longissimus lumborum & 76.6 & $75.7^{\mathrm{abc}}$ & $78.4^{\mathrm{a}}$ & $78.1^{\mathrm{ab}}$ & $77.9^{\mathrm{bcd}}$ \\
\hline Upper 2/3 Choice & Longissimus lumborum & 67.9 & $69.9^{\text {bcde }}$ & $68.8^{\mathrm{abcd}}$ & $69.2^{\mathrm{bc}}$ & $69.8^{\mathrm{de}}$ \\
\hline Low Choice & Longissimus lumborum & 71.3 & $67.8^{\text {cde }}$ & $73.6^{\mathrm{abc}}$ & $68.4^{\mathrm{bc}}$ & $70.6^{\text {cde }}$ \\
\hline Select & Longissimus lumborum & 60.4 & $59.3^{\text {ef }}$ & $64.6^{\text {bcde }}$ & $61.9^{\mathrm{cd}}$ & $62.3^{\mathrm{efg}}$ \\
\hline Standard & Longissimus lumborum & 68.2 & $59.2^{\text {ef }}$ & $56.4^{\mathrm{ef}}$ & $58.7^{\mathrm{cd}}$ & $60.8^{\mathrm{efg}}$ \\
\hline Prime & Gluteus medius & 54.9 & $62.5^{\text {def }}$ & $65.2^{\text {bcde }}$ & $63.4^{\mathrm{cd}}$ & $62.7^{\mathrm{efg}}$ \\
\hline Upper 2/3 Choice & Gluteus medius & 61.2 & $69.2^{\text {bcde }}$ & $72.9^{\mathrm{abc}}$ & $69.5^{\mathrm{bc}}$ & $67.8^{\mathrm{def}}$ \\
\hline Low Choice & Gluteus medius & 47.6 & $60.2^{\mathrm{ef}}$ & $61.3^{\text {bcdef }}$ & $58.0^{\text {cde }}$ & $55.6^{\text {efgh }}$ \\
\hline Select & Gluteus medius & 51.9 & $50.4^{\mathrm{fgh}}$ & $57.2^{\mathrm{def}}$ & $54.9^{\text {cde }}$ & $55.4^{\text {efgh }}$ \\
\hline Standard & Gluteus medius & 48.1 & $50.8^{\text {fgh }}$ & $56.6^{\mathrm{def}}$ & $51.6^{\mathrm{def}}$ & $52.2^{\mathrm{ghi}}$ \\
\hline Prime & Semimembranosus & 36.6 & $62.7^{\text {def }}$ & $59.7^{\text {cdef }}$ & $52.1^{\operatorname{def}}$ & $52.9^{\text {fghi }}$ \\
\hline Upper 2/3 Choice & Semimembranosus & 33.9 & $61.6^{\mathrm{def}}$ & $56.8^{\mathrm{def}}$ & $41.6^{\mathrm{ef}}$ & $44.8^{\mathrm{hi}}$ \\
\hline Low Choice & Semimembranosus & 32.2 & $38.6^{\mathrm{h}}$ & $49.4^{\mathrm{f}}$ & $37.2^{\mathrm{f}}$ & $39.1^{\mathrm{i}}$ \\
\hline Select & Semimembranosus & 39.4 & $55.1^{\mathrm{fg}}$ & $64.9^{\text {bcde }}$ & $57.5^{\text {cde }}$ & $55.6^{\mathrm{efgh}}$ \\
\hline Standard & Semimembranosus & 42.3 & $44.3^{\mathrm{gh}}$ & $52.5^{\mathrm{ef}}$ & $44.4^{\mathrm{ef}}$ & $46.2^{\mathrm{hi}}$ \\
\hline Std. Error & & 7.5 & 7.1 & 7.3 & 7.8 & 7.0 \\
\hline \multirow[t]{7}{*}{$P$ value } & & 0.107 & 0.024 & 0.032 & 0.019 & 0.033 \\
\hline & Psoas major & $89.4^{\mathrm{a}}$ & 76.6 & 79.9 & 82.7 & 83.2 \\
\hline & Longissimus lumborum & $69.4^{\mathrm{b}}$ & 66.4 & 68.3 & 67.3 & 68.3 \\
\hline & Gluteus medius & $54.1^{\mathrm{c}}$ & 58.6 & 62.6 & 59.5 & 58.7 \\
\hline & Semimembranosus & $38.4^{\mathrm{d}}$ & 52.5 & 56.6 & 46.6 & 47.7 \\
\hline & Std. Error & 3.7 & 3.4 & 3.0 & 3.1 & 2.9 \\
\hline & $P$ value & $<0.001$ & $<0.001$ & $<0.001$ & $<0.001$ & $<0.001$ \\
\hline Prime & & 68.8 & 71.7 & 72.0 & 70.7 & 70.8 \\
\hline Upper 2/3 Choice & & 61.1 & 71.8 & 71.2 & 67.1 & 66.8 \\
\hline Low Choice & & 57.8 & 55.5 & 63.0 & 57.7 & 59.2 \\
\hline Select & & 63.3 & 59.6 & 67.9 & 65.2 & 65.2 \\
\hline Standard & & 63.0 & 58.9 & 60.3 & 59.4 & 60.4 \\
\hline Std. Error & & 5.9 & 3.2 & 3.8 & 4.2 & 4.1 \\
\hline$P$ value & & 0.735 & $<0.001$ & 0.135 & 0.174 & 0.268 \\
\hline
\end{tabular}

abcdefghi Means within a column lacking a common superscript differ $(P<0.05)$.

${ }^{1}$ Consumer rated each steak on a $100-\mathrm{mm}$ continuous line scale for flavor, tenderness, juiciness, and overall liking.

On the scale, 0 was verbally anchored as not tender, not juicy, dislike flavor extremely, and dislike overall extremely. Similarly, 100 was verbally anchored as very tender, very juicy, like flavor extremely, and like overall extremely. Meat quality, 4 variables score (MQ4) reflecting a weighted consumer score between 1 and 100 was calculated using standard Meat Standard Australia weightings of $30 \%$ for tenderness, flavor and overall liking and $10 \%$ for juiciness. 
Table 3. Least-squares means of volatile flavor compounds (ng) from grilled beef steaks of four muscles

\begin{tabular}{|c|c|c|c|c|c|c|c|}
\hline \multirow[b]{2}{*}{ Volatile compound } & \multirow{2}{*}{$\begin{array}{l}\text { Linear } \\
\text { Retention } \\
\text { Indices }\end{array}$} & \multicolumn{4}{|c|}{ Beef Muscles } & \multirow[b]{2}{*}{$\begin{array}{l}\text { Std. } \\
\text { Error }\end{array}$} & \multirow[b]{2}{*}{$P$ value } \\
\hline & & $\begin{array}{c}\text { Longissimus } \\
\text { lumborum }\end{array}$ & $\begin{array}{l}\text { Psoas } \\
\text { major }\end{array}$ & $\begin{array}{l}\text { Gluteus } \\
\text { medius }\end{array}$ & $\begin{array}{c}\text { Semi- } \\
\text { membranosus }\end{array}$ & & \\
\hline \multicolumn{8}{|l|}{ n-Aldehydes } \\
\hline Acetaldehyde & 412 & $2.52^{\mathrm{b}}$ & $6.77^{\mathrm{a}}$ & $2.05^{\mathrm{b}}$ & $1.59^{\mathrm{b}}$ & 0.81 & $<0.001$ \\
\hline Pentanal & 697 & 28.65 & 33.39 & 34.84 & 38.29 & 9.99 & 0.859 \\
\hline Hexanal & 795 & 12.24 & 10.01 & 13.72 & 15.18 & 4.68 & 0.779 \\
\hline Heptanal & 898 & 0.83 & 1.09 & 1.28 & 1.27 & 0.16 & 0.051 \\
\hline Octanal & 1002 & 0.79 & 1.17 & 1.11 & 1.18 & 0.18 & 0.188 \\
\hline Nonanal & 1107 & 1.36 & 1.96 & 1.94 & 1.89 & 0.24 & 0.103 \\
\hline Decanal & 1205 & 0.22 & 0.18 & 0.28 & 0.23 & 0.04 & 0.219 \\
\hline Sum n-Aldehydes & & 44.16 & 47.55 & 53.08 & 57.48 & 15.16 & 0.858 \\
\hline \multicolumn{8}{|l|}{ Strecker Aldehydes } \\
\hline 3-Methyl butanal & 652 & 52.43 & 39.74 & 41.75 & 50.49 & 9.21 & 0.467 \\
\hline 2-Methyl butanal & 659 & 87.38 & 49.28 & 71.21 & 84.45 & 15.03 & 0.139 \\
\hline Benzaldehyde & 960 & $0.36^{\mathrm{b}}$ & $0.58^{\mathrm{a}}$ & $0.54^{\mathrm{a}}$ & $0.48^{\mathrm{a}}$ & 0.04 & $<0.001$ \\
\hline Phenylacetaldehyde & 1045 & 0.06 & 0.07 & 0.07 & 0.07 & 0.01 & 0.711 \\
\hline Sum Strecker aldehydes & & 139.99 & 90.44 & 114.53 & 136.55 & 24.81 & 0.277 \\
\hline \multicolumn{8}{|l|}{ Ketones } \\
\hline 2-Propanone & 496 & $2.85^{\mathrm{b}}$ & $13.97^{\mathrm{a}}$ & $3.78^{\mathrm{b}}$ & $4.55^{\mathrm{b}}$ & 1.49 & $<0.001$ \\
\hline 2,3-Butanedione & 560 & $6.87^{\mathrm{bc}}$ & $6.34^{\mathrm{c}}$ & $9.45^{\mathrm{ab}}$ & $10.53^{\mathrm{a}}$ & 1.39 & 0.033 \\
\hline 2-Butanone & 597 & 1.94 & 2.84 & 1.92 & 1.99 & 0.43 & 0.235 \\
\hline 3-Hydroxy-2-butanone & 705 & $61.44^{\mathrm{b}}$ & $65.59^{\mathrm{b}}$ & $135.28^{\mathrm{a}}$ & $123.33^{\mathrm{a}}$ & 13.11 & $<0.001$ \\
\hline \multicolumn{8}{|l|}{ Sulfides } \\
\hline Dimethyl sulfide & 519 & $0.41^{\mathrm{c}}$ & $3.03^{\mathrm{a}}$ & $1.03^{\mathrm{bc}}$ & $1.38^{\mathrm{b}}$ & 0.42 & $<0.001$ \\
\hline Dimethyl disulfide & 744 & 0.35 & 0.52 & 0.32 & 0.28 & 0.07 & 0.065 \\
\hline \multicolumn{8}{|l|}{ Thiols } \\
\hline Methanethiol & 423 & 0.02 & 0.04 & 0.02 & 0.03 & 0.01 & 0.134 \\
\hline Methional & 911 & 0.23 & 0.28 & 0.28 & 0.25 & 0.04 & 0.504 \\
\hline Sum Sulfur containing & & $1.02^{\mathrm{b}}$ & $3.81^{\mathrm{a}}$ & $1.63^{\mathrm{b}}$ & $1.95^{\mathrm{b}}$ & 0.44 & $<0.001$ \\
\hline \multicolumn{8}{|l|}{ Furans } \\
\hline 2-Pentyl furan & 994 & 0.03 & 0.06 & 0.05 & 0.06 & 0.02 & 0.359 \\
\hline \multicolumn{8}{|l|}{ Pyrazines } \\
\hline Methyl pyrazine & 833 & $0.24^{\mathrm{a}}$ & $0.12^{\mathrm{b}}$ & $0.16^{\mathrm{ab}}$ & $0.08^{\mathrm{b}}$ & 0.05 & 0.029 \\
\hline 2-5/6-Dimethyl pyrazine & 925 & 0.73 & 0.35 & 0.56 & 0.29 & 0.18 & 0.100 \\
\hline Trimethyl pyrazine & 1000 & 0.19 & 0.91 & 0.17 & 0.73 & 0.05 & 0.172 \\
\hline 2-Ethyl-3,5/6-dimethyl pyrazine & 1086 & 0.09 & 0.07 & 0.12 & 0.06 & 0.02 & 0.184 \\
\hline Sum pyrazines & & 1.25 & 0.64 & 1.01 & 0.52 & 0.29 & 0.079 \\
\hline Alkanes & 700 & & & & & & \\
\hline Heptane & 800 & $30.83^{\mathrm{b}}$ & $57.63^{\mathrm{a}}$ & $40.83^{\mathrm{ab}}$ & $42.35^{\mathrm{ab}}$ & 7.89 & 0.034 \\
\hline Octane & & $1.36^{\mathrm{b}}$ & $2.15^{\mathrm{a}}$ & $1.77^{\mathrm{ab}}$ & $1.71^{\mathrm{ab}}$ & 0.23 & 0.014 \\
\hline
\end{tabular}




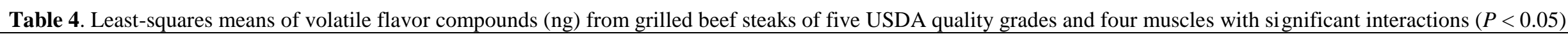

\begin{tabular}{|c|c|c|c|c|c|c|c|c|c|}
\hline $\begin{array}{c}\text { USDA Quality } \\
\text { Grade }\end{array}$ & Muscle & Acetaldehyde & 2-Propanone & $\begin{array}{l}\text { Dimethyl } \\
\text { sulfide }\end{array}$ & Hexanal & Benzaldehyde & Octanal & Nonanal & $\begin{array}{c}\text { Sum } \\
\text { Sulfur } \\
\text { containing }\end{array}$ \\
\hline Prime & Psoas major & $1.46^{\mathrm{c}}$ & $5.81^{\mathrm{cd}}$ & $0.91^{\mathrm{cd}}$ & $5.23^{\mathrm{bcd}}$ & $0.26^{\mathrm{e}}$ & $0.69^{\text {cd }}$ & $1.47^{\mathrm{bcd}}$ & $1.04^{\mathrm{ed}}$ \\
\hline Upper 2/3 Choice & Psoas major & $18.39^{\mathrm{a}}$ & $35.55^{\mathrm{a}}$ & $9.44^{\mathrm{a}}$ & $4.12^{\mathrm{bcd}}$ & $0.91^{\mathrm{a}}$ & $0.51^{\mathrm{cd}}$ & $1.26^{\mathrm{bcd}}$ & $10.59^{\mathrm{a}}$ \\
\hline Low Choice & Psoas major & $2.28^{\mathrm{c}}$ & $1.92^{\mathrm{cd}}$ & $0.58^{\mathrm{cd}}$ & $3.91^{\mathrm{cd}}$ & $0.55^{\mathrm{bcd}}$ & $0.57^{\mathrm{cd}}$ & $1.10^{\mathrm{cd}}$ & $1.57^{\text {cde }}$ \\
\hline Select & Psoas major & $9.43^{b}$ & $15.72^{\mathrm{b}}$ & $3.54^{\mathrm{b}}$ & $9.66^{\mathrm{bcd}}$ & $0.72^{\mathrm{ab}}$ & $1.98^{\mathrm{ab}}$ & $2.29^{\mathrm{bc}}$ & $4.44^{\mathrm{b}}$ \\
\hline Standard & Psoas major & $2.28^{\mathrm{c}}$ & $10.83^{\mathrm{bc}}$ & $0.97^{\mathrm{cd}}$ & $27.12^{\mathrm{ab}}$ & $0.47^{\text {cde }}$ & $2.11^{\mathrm{a}}$ & $3.69^{\mathrm{a}}$ & $1.39^{\mathrm{de}}$ \\
\hline Prime & Longissimus lumborum & $2.90^{\mathrm{c}}$ & $4.13^{\mathrm{cd}}$ & $0.49^{\mathrm{d}}$ & $9.00^{\mathrm{bcd}}$ & $0.28^{\mathrm{e}}$ & $0.41^{\mathrm{d}}$ & $0.72^{\mathrm{d}}$ & $1.01^{\mathrm{e}}$ \\
\hline Upper 2/3 Choice & Longissimus lumborum & $3.15^{\mathrm{c}}$ & $2.32^{\mathrm{cd}}$ & $0.19^{\mathrm{d}}$ & $10.83^{\mathrm{bcd}}$ & $0.33^{\mathrm{de}}$ & $0.72^{\mathrm{cd}}$ & $1.21^{\mathrm{cd}}$ & $0.75^{\mathrm{e}}$ \\
\hline Low Choice & Longissimus lumborum & $1.64^{\mathrm{c}}$ & $3.00^{\mathrm{cd}}$ & $0.38^{\mathrm{d}}$ & $10.87^{\mathrm{bcd}}$ & $0.34^{\mathrm{de}}$ & $0.81^{\mathrm{cd}}$ & $1.43^{\mathrm{bcd}}$ & $1.01^{\mathrm{e}}$ \\
\hline Select & Longissimus lumborum & $2.35^{\mathrm{c}}$ & $3.29^{\mathrm{cd}}$ & $0.69^{\mathrm{cd}}$ & $12.22^{\mathrm{bcd}}$ & $0.40^{\mathrm{de}}$ & $0.78^{\mathrm{cd}}$ & $1.32^{\mathrm{bcd}}$ & $1.36^{\mathrm{ed}}$ \\
\hline Standard & Longissimus lumborum & $2.56^{\mathrm{c}}$ & $1.53^{\mathrm{d}}$ & $0.30^{\mathrm{d}}$ & $18.28^{\mathrm{abcd}}$ & $0.46^{\text {cde }}$ & $1.23^{\mathrm{bc}}$ & $2.14^{\mathrm{bc}}$ & $0.98^{\mathrm{e}}$ \\
\hline Prime & Gluteus medius & $1.53^{\mathrm{c}}$ & $3.11^{\mathrm{cd}}$ & $0.68^{\mathrm{cd}}$ & $7.55^{\mathrm{bcd}}$ & $0.42^{\text {de }}$ & $0.76^{\mathrm{cd}}$ & $1.30^{\mathrm{bcd}}$ & $0.15^{\mathrm{ed}}$ \\
\hline Upper 2/3 Choice & Gluteus medius & $2.29^{c}$ & $9.62^{\mathrm{bc}}$ & $2.55^{\mathrm{bc}}$ & $13.79^{\mathrm{bcd}}$ & $0.39^{\mathrm{de}}$ & $0.88^{\mathrm{cd}}$ & $1.64^{\mathrm{bcd}}$ & $3.00^{\mathrm{bcd}}$ \\
\hline Low Choice & Gluteus medius & $3.33^{\mathrm{c}}$ & $2.66^{\mathrm{cd}}$ & $0.92^{\mathrm{cd}}$ & $21.13^{\mathrm{abc}}$ & $0.52^{\text {bcd }}$ & $1.37^{\mathrm{abc}}$ & $2.25^{\mathrm{bc}}$ & $1.57^{\mathrm{de}}$ \\
\hline Select & Gluteus medius & $1.63^{c}$ & $1.37^{\mathrm{d}}$ & $0.45^{\mathrm{d}}$ & $16.48^{b c d}$ & $0.82^{\mathrm{a}}$ & $1.57^{\mathrm{abc}}$ & $2.44^{\mathrm{b}}$ & $1.29^{\mathrm{ed}}$ \\
\hline Standard & Gluteus medius & $1.46^{\mathrm{c}}$ & $2.15^{\mathrm{cd}}$ & $0.56^{\mathrm{cd}}$ & $9.64^{\mathrm{bcd}}$ & $0.58^{\mathrm{bcd}}$ & $0.99^{\mathrm{cd}}$ & $2.05^{\mathrm{bc}}$ & $1.24^{\mathrm{ed}}$ \\
\hline Prime & Semimembranosus & $1.77^{\mathrm{c}}$ & $3.82^{\mathrm{cd}}$ & $0.91^{\mathrm{cd}}$ & $25.81^{\mathrm{abc}}$ & $0.66^{\mathrm{abc}}$ & $1.57^{\mathrm{abc}}$ & $2.18^{\mathrm{bc}}$ & $1.56^{\mathrm{ed}}$ \\
\hline Upper 2/3 Choice & Semimembranosus & $1.81^{\mathrm{c}}$ & $1.21^{\mathrm{d}}$ & $0.28^{\mathrm{d}}$ & $4.64^{\mathrm{bcd}}$ & $0.42^{\text {de }}$ & $0.73^{\mathrm{cd}}$ & $1.33^{\mathrm{bccd}}$ & $0.77^{\mathrm{e}}$ \\
\hline Low Choice & Semimembranosus & $3.08^{c}$ & $9.73^{b c}$ & $3.49^{\mathrm{b}}$ & $7.55^{\mathrm{bcd}}$ & $0.39^{\text {de }}$ & $1.21^{\mathrm{bc}}$ & $2.14^{\mathrm{bc}}$ & $4.01^{\mathrm{bc}}$ \\
\hline Select & Semimembranosus & $0.27^{\mathrm{c}}$ & $2.75^{\mathrm{cd}}$ & $0.61^{\mathrm{cd}}$ & $35.74^{\mathrm{a}}$ & $0.40^{\mathrm{de}}$ & $1.55^{\mathrm{abc}}$ & $2.37^{\mathrm{bc}}$ & $1.17^{\mathrm{ed}}$ \\
\hline Standard & Semimembranosus & $1.37^{\mathrm{c}}$ & $5.26^{\mathrm{cd}}$ & $1.63^{\mathrm{bcd}}$ & $2.18^{\mathrm{d}}$ & $0.52^{\text {bcd }}$ & $0.84^{\mathrm{cd}}$ & $1.40^{\mathrm{bcd}}$ & $2.22^{\text {bcde }}$ \\
\hline \multirow{2}{*}{\multicolumn{2}{|c|}{$\begin{array}{l}\text { Std. Error } \\
P \text { value }\end{array}$}} & 1.29 & 2.75 & 0.74 & 7.29 & 0.08 & 0.31 & 0.41 & 0.72 \\
\hline & & $<0.001$ & $<0.001$ & $<0.001$ & 0.017 & $<0.001$ & 0.028 & 0.037 & $<0.001$ \\
\hline
\end{tabular}

$610 \quad{ }^{\text {abcde }}$ Means within a column lacking a common superscript differ $(P<0.05)$. 
Table 5. Pearson correlation coefficients ( $\mathrm{r}$ ) of consumer palatability scores ${ }^{1}$ and proximate data ${ }^{2}$ of grilled beef steaks from five USDA Quality Grades ${ }^{3}$ and four muscles ${ }^{4}$

\begin{tabular}{lccccccc}
\hline & Overall Liking & Tenderness & Juiciness & Flavor Liking & $\%$ Collagen & $\%$ Fat & $\%$ Moisture \\
\hline Tenderness & $0.79^{* * *}$ & & & & & & \\
Juiciness & $0.75^{* * *}$ & $0.65^{* * *}$ & & & & & \\
Flavor & $0.85^{* * *}$ & $0.61^{* * *}$ & $0.65^{* * *}$ & & & & \\
$\%$ Collagen & $0.10^{*}$ & 0.01 & $0.14^{* *}$ & $0.13^{*}$ & & & \\
$\%$ Fat & $0.27^{* * *}$ & $0.22^{* * *}$ & $0.29^{* * *}$ & $0.27^{* * *}$ & $0.70^{* * *}$ & & \\
$\%$ Moisture & $-0.23^{* * *}$ & $-0.16^{* * *}$ & $-0.24^{* * *}$ & $-0.23^{* * *}$ & $-0.68^{* * *}$ & $-0.97^{* * *}$ & \\
$\%$ Protein & $-0.28^{* * *}$ & $-0.25^{* * *}$ & $-0.29^{* * *}$ & $-0.26^{* * *}$ & $-0.57^{* * *}$ & $-0.64^{* * *}$ & $0.50^{* * *}$ \\
\hline
\end{tabular}

${ }^{1}$ Consumer rated each steak on a 100-mm continuous line scale for flavor, tenderness, juiciness, and overall liking. On the scale, 0 was verbally anchored as not tender, not juicy, dislike flavor extremely, and dislike overall extremely. Similarly, 100 was verbally anchored as very tender, very juicy, like flavor extremely, and like overall extremely.

${ }^{2}$ Chemical percentages of fat, moisture, protein, and collagen determined of raw steaks by AOAC official method (2007.04; Anderson, 2007).

${ }^{3}$ Beef quality grades included: Prime, Upper 2/3 Choice, Low Choice, Select, and Standard.

${ }^{4}$ Beef muscles included: Psoas major, Longissimus lumborum, Gluteus medius, and Semimembranosus.

* Significant correlation $(P<0.05)$

${ }^{* *}$ Significant correlation $(P<0.01)$

*** Significant correlation $(P<0.001)$ 
Table 6. Pearson correlation coefficients (r) between $n$-aldehydes, flavor liking ${ }^{1}$, overall liking ${ }^{1}$ and $\%$ fat $^{2}$ for grilled beef steaks from five USDA Quality Grades ${ }^{3}$ and four muscles ${ }^{4}$

\begin{tabular}{lccc}
\hline & Flavor liking & Overall liking & \% Fat \\
\hline$n$-Aldehydes & & & \\
Pentanal & -0.15 & -0.13 & -0.16 \\
Hexanal & -0.17 & -0.14 & -0.16 \\
Heptanal & -0.18 & -0.16 & $-0.28^{* *}$ \\
Octanal & -0.19 & -0.15 & $-0.39^{* * *}$ \\
Nonanal & $-0.24^{*}$ & -0.17 & $-0.41^{* * *}$ \\
Decanal & $-0.25^{*}$ & $-0.22^{*}$ & -0.19 \\
Sum $\mathrm{C}_{5}-\mathrm{C}_{10}$ n-Aldehydes & -0.18 & -0.15 & -0.17 \\
\hline
\end{tabular}

$621{ }^{1}$ Consumer rated each steak on a 100-mm continuous line scale for flavor liking and overall

622 liking. On the scale, 0 was verbally anchored as dislike flavor extremely, and dislike overall

623 extremely. Similarly, 100 was verbally anchored as like flavor extremely, and like overall

624 extremely.

$625{ }^{2}$ Chemical percentages of fat, moisture, protein, and collagen determined of raw steaks by

626 AOAC official method (2007.04; Anderson, 2007).

$627{ }^{3}$ Beef quality grades included: Prime, Upper 2/3 Choice, Low Choice, Select, and Standard.

$628{ }^{4}$ Beef muscles included: Psoas major, Longissimus lumborum, Gluteus medius, and

629 Semimembranosus.

$630 *$ Significant correlation $(P<0.05)$

$631{ }^{* *}$ Significant correlation $(P<0.01)$

$632{ }^{* * *}$ Significant correlation $(P<0.001)$ 


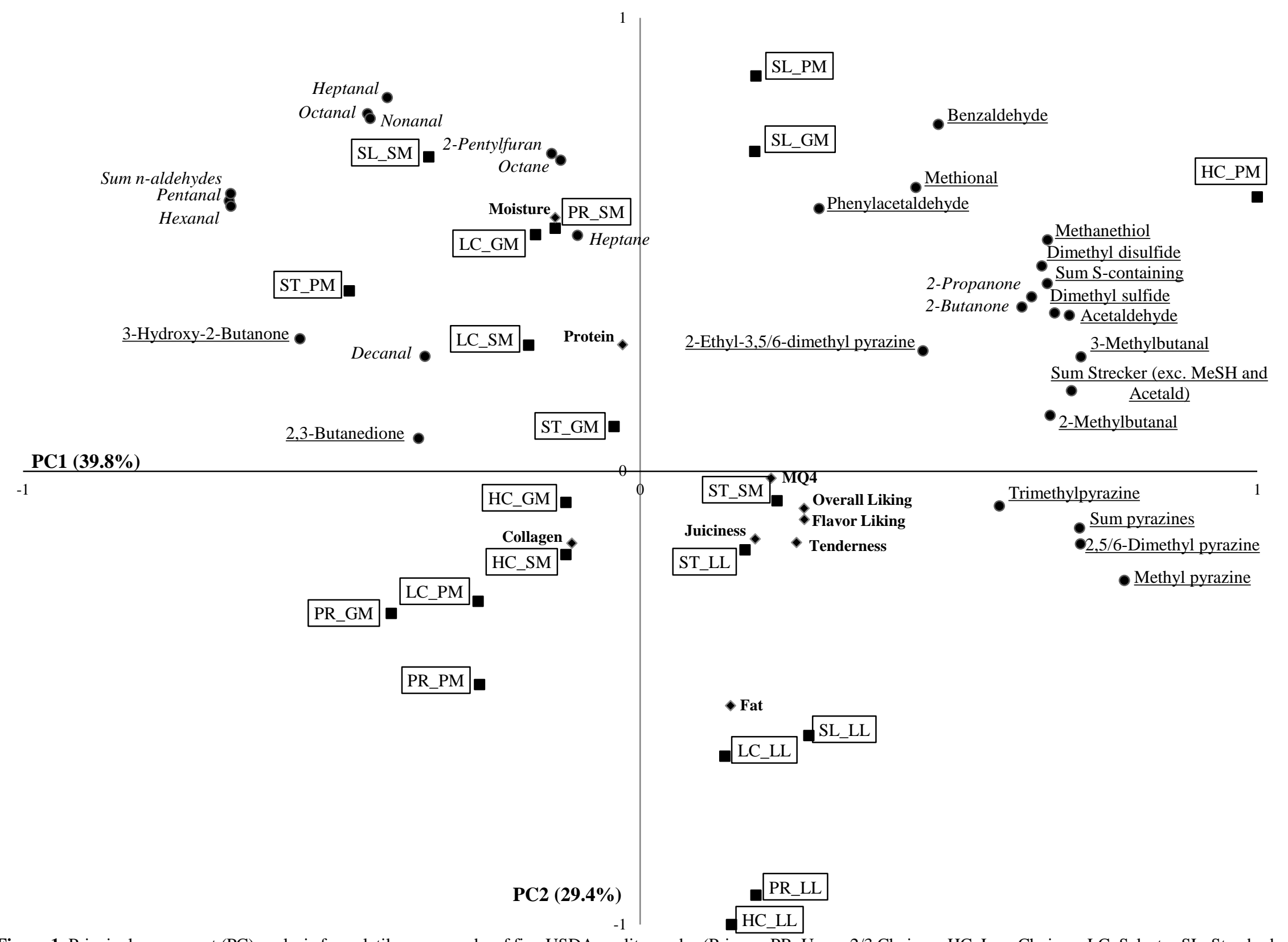

Figure 1. Principal component $(\mathrm{PC})$ analysis for volatile compounds, of five USDA quality grades (Prime $=$ PR, Upper 2/3 Choice $=$ HC, Low Choice $=$ LC, Select $=$ SL, Standard $=$ ST) and four muscles (Psoas major $=$ PM, Longissimus lumborum $=$ LL, Gluteus medius $=$ GM, Semimembranosus $=$ SM). Volatile compound groups shown with different formatting: Maillard products and lipid oxidation products. Consumer palatability traits and proximate data $(\%)$ were correlated on the same axes. 


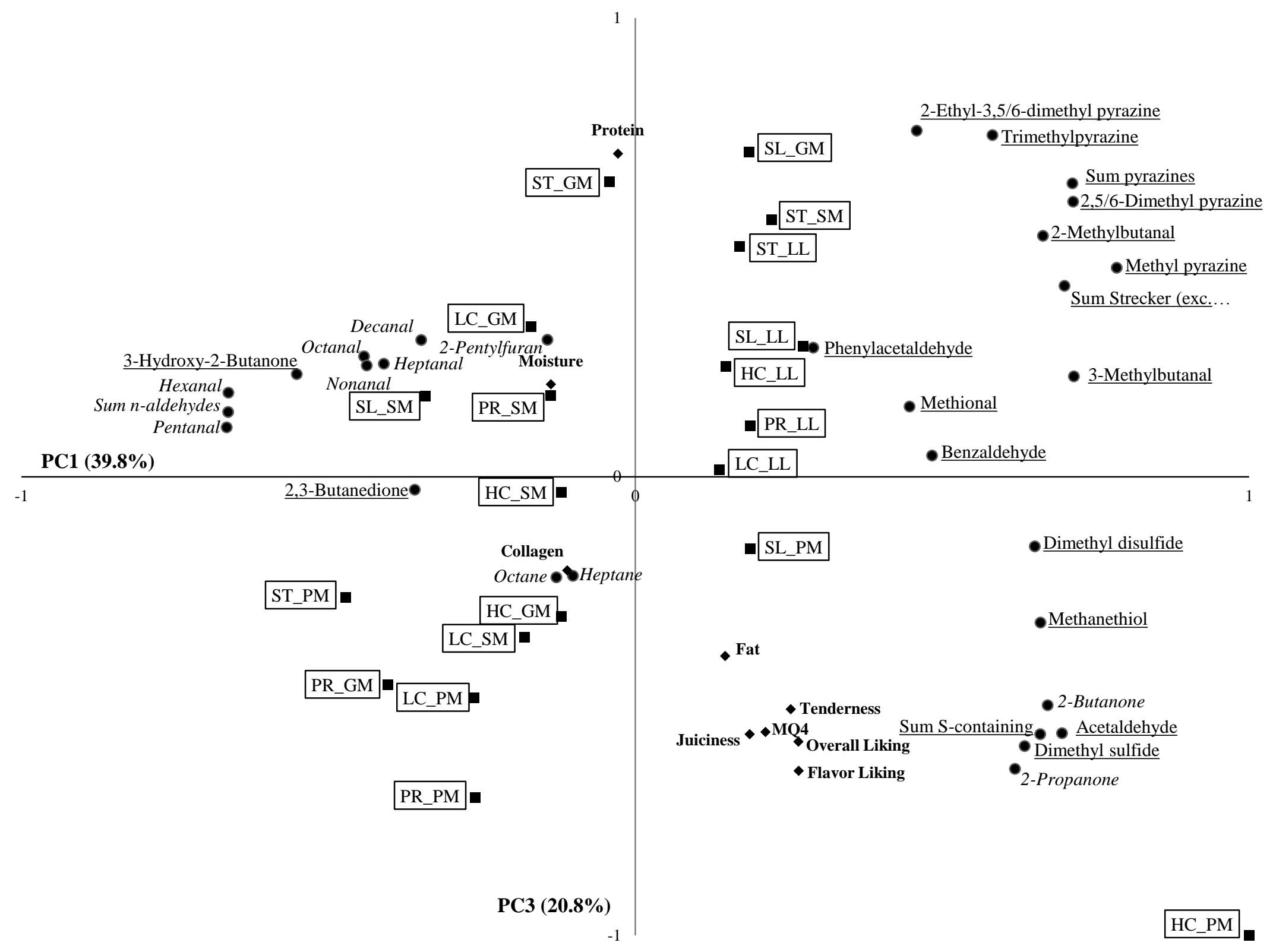

Figure 2. Principal component (PC) analysis for volatile compounds, of five USDA quality grades (Prime $=$ PR, Upper 2/3 Choice $=$ HC, Low Choice $=$ LC, Select $=$ SL, Standard $=$ ST) and four muscles (Psoas major $=$ PM, Longissimus lumborum = LL, Gluteus medius = GM, Semimembranosus = SM). Volatile compound groups shown with different formatting: Maillard products and lipid oxidation products. Consumer palatability traits and proximate data $(\%)$ were correlated on the same axes. 